\title{
EVALUASI TEGANGAN-REGANGAN LERENG JALAN AMPENAN - PEMENANG KM. 12+800 (STUDI KASUS LONGSORAN LERENG TANJAKAN ALBERTO SENGGIGI)
}

\author{
Sukandi' ${ }^{1}$ dan Bq. Malikah $\mathrm{Hr}^{2}$
}

1Prodi Teknik Sipil, Fakultas Sains, Teknik dan Terapan, Universitas Pendidikan Mandalika, Jl. Pemuda No. 59A, Kota Mataram, 83125

Email : sukandi.geoteknik@gmail.com

2Prodi Teknik Sipil, Fakultas Sains, Teknik dan Terapan, Universitas Pendidikan Mandalika, Jl. Pemuda No. 59A, Kota Mataram, 83125

Email : bq.malikah.hr@gmail.com

\begin{abstract}
ABSTRAK
Pengembangan pariwisata di Nusa Tenggara Barat, khususnya di Pulau Lombok terus mengalami peningkatan, sehingga dilakukan perbaikan fasilitas untuk memperindah pemandangan. Salah satu fasilitas yang diperbaiki adalah penambahan trotoar jalan yang menggantung kearah lereng pada ruas jalan Ampenan-Pemenang KM. 12+800 tanjakan Cafe Alberto Senggigi. Dampak dari penambahan trotoar tersebut memiliki risiko terhadap gerakan massa tanah/batuan dasar, hal ini ditandai dengan adanya retakan memanjang sejajar jalan. Adanya retakan yang disertai curah hujan tinggi menjadi pemicu terjadinya longsoran pada tanggal 6 Februari tahun 2021 karena naiknya muka air tanah. Untuk melihat terjadinya longsoran akibat kenaikan muka air tanah, maka dilakukan evaluasi terhadap tegangan regangan yang terjadi pada lereng jalan dengan simulasi numeris. Metode yang digunakan yaitu melakukan kajian data laboratorium dan bore log yang digunakan sebagai parameter input dalam simulasi. Simulasi numeris di idealisasi 2D pada kondisi plane strain menggunakan model Mohr-Coulomb untuk tanah/batuan dasar, sedangkan pasangan batu dan trotoar beton di dekati dengan model linear elastic. Simulasi numeris dengan Plaxis dilakukan dalam kondisi sebelum dan setelah muka air tanah mengalami kenaikan dengan model geometri berdasarkan stratigrafi hasil penyelidikan geoteknik. Hasil simulasi numeris dengan Plaxis menunjukkan tegangan - regangan mengalami peningkatan setelah muka air tanah naik akibat curah hujan yang tinggi. Kondisi lereng sebelum terjadi kenaikan muka air tanah tergolong stabil karena angka aman (SF) 1.3379. Kenaikan muka air tanah pada lereng menyebabkan kestabilan lereng menjadi tidak stabil karena angka aman (SF) 1.1602. Angka aman yang diperoleh setelah muka air tanah naik kurang dari syarat 1.2 sehingga lereng jalan mengalami kelongsoran.
\end{abstract}

Kata kunci: gerakan massa, muka air tanah, simulasi numeris, tegangan - regangan

\begin{abstract}
The development of tourism in West Nusa Tenggara, especially on the island of Lombok continues to increase, so that improvements are made to facilities to beautify the scenery. One of the improved facilities is the addition of road pavements that hang towards the slopes on the Ampenan-Pemenang KM road segment. 12+800 climbs Cafe Alberto Senggigi. The impact of the addition of the sidewalk has a risk of the movement of the soil/bedrock mass, this is indicated by the presence of longitudinal cracks parallel to the road. The existence of cracks accompanied by high rainfall triggered an avalanche on February 6, 2021 due to rising ground water levels. To see the occurrence of landslides due to the increase in ground water level, an evaluation of the stress strain that occurs on the road slopes is carried out with numerical simulations. The method used is to study laboratory data and bore logs which are used as input parameters in the simulation. The numerical simulation is idealized in 2D under plane strain conditions using the Mohr-Coulomb model for soil/bedrock, while retaining walls and concrete pavements are approximated by linear elastic models. Numerical simulations with Plaxis were carried out in conditions before and after the groundwater level had increased with a geometric model based on the stratigraphy results of geotechnical investigations. The results of numerical simulations using Plaxis show that stress-
\end{abstract}


strain increases after the groundwater level rises due to high rainfall. The condition of the slope before the groundwater level rise is relatively stable because the safe number (SF) is 1.3379. The increase in groundwater level on the slopes causes the slope stability to become unstable because the safe number (SF) is 1.1602. The safe number obtained after the groundwater level rises is less than the 1.2 requirement so that the road slopes experience a landslide.

Keywords: mass movement, groundwater level, numerical simulation, stress - strain

\section{PENDAHULUAN}

Pengembangan pariwisata di Nusa Tenggara Barat, khususnya di Pulau Lombok terus mengalami peningkatan, ini ditunjukkan dengan beberapa destinasi wisata yang mengalami perbaikan baik dari segi fasilitas maupun sarana dan prasarana yang ada. Perbaikan fasilitas maupun sarana dan prasarana yang sebelumnya dimaksudkan untuk memperindah pemandangan akan tetapi tidak disertai dengan perencanaan yang baik. Sebagai salah satu contoh kasus adalah penambahan trotoar jalan yang menggantung kearah lereng pada ruas jalan Ampenan-Pemenang KM. 12+800 tanjakan Cafe Alberto Senggigi.

Dari hasil observasi lapangan, penambahan trotoar jalan tidak memperhatikan kondisi lereng, baik dari kemiringan lereng, tinggi lereng, jenis tanah maupun batuan yang ada. Pembangunan trotoar hanya diletakkan dibahu jalan di atas dinding penahan tanah yang sudah ada tanpa ada perbaikan pondasi dinding penahan. Selain itu, ditemukan bahwa pondasi dinding penahan tanah di kaki lereng sudah mengalami abrasi akibat tekanan air laut yang mengarah kearah kaki lereng.

Dampak dari pembangunan trotoar jalan tersebut memiliki risiko terhadap gerakan massa tanah/batuan, ini dikarenakan lereng mengalami penambahan beban. Gerakan massa tanah/batuan umumnya disebabkan oleh gaya gravitasi, tekanan air pori, getaran atau gempa dapat jadi pemicunya. Gerakan massa terjadi akibat adanya teganganregangan di sepanjang bidang runtuh yang merupakan batas bergeraknya massa tanah/batuan. Longsoran, umumnya terjadi saat tegangan geser rata-rata di sepanjang bidang longsor sama dengan kuat geser massa tanah/batuan. Akan tetapi, saat terjadi keruntuhan bertahap, longsoran tanah terjadi pada tegangan geser yang kurang dari kuat geser puncaknya.

Salah satu kasus gerakan massa tanah/batuan adalah terjadinya longsoran lereng ruas jalan Ampenan-Pemenang KM 12+800 ditanjakan dekat Cafe Alberto Senggigi yang terjadi pada tanggal 6 Februari tahun 2021. Sebelum terjadi longsoran, terlebih dahulu lereng jalan mengalami gejala geologi, yaitu adanya retakan memanjang sejajar jalan. Adanya retakan yang disertai curah hujan tinggi dapat menjadi pemicu terjadinya longsoran. Air yang masuk melalui retakan menyebabkan muka air tanah naik sehingga tanah menjadi jenuh karena rongga pori terisi air yang berakibat pada tekanan air pori. Bertambahnya tekanan air pori menyebabkan tekanan efektif tanah menjadi berkurang sehingga berpotensi untuk terjadi longsor.

Untuk melihat terjadinya longsoran akibat kenaikan muka air tanah, maka perlu dilakukan evaluasi terhadap tegangan regangan yang terjadi pada lereng jalan. Salah satu metode yang digunakan untuk melakukan evaluasi adalah menerapkan metode elemen hingga berupa simulasi numeris. Dalam penelitian ini, simulasi numeris menggunakan Software Plaxis untuk menghitung tegangan - regangan sehingga deformasi dan stabilitas dapat diketahui.

Tujuan penelitian ini adalah untuk mengetahui tegangan - regangan lereng dengan simulasi numeris akibat dari kenaikan muka air tanah. 


\section{TINJAUAN PUSTAKA}

\section{Longsoran}

Longsor merupakan gerakan massa tanah/batuan yang disebabkan oleh gayagaya gravitasi, getaran atau gempa. Gerakan massa tanah/massa batuan terjadi akibat adanya keruntuhan geser disepanjang bidang longsor sebagai batas bergeraknya massa tanah/batuan. Longsoran merupakan salah satu jenis gerakan tanah/batuan [1].

Banyak peristiwa longsoran dipicu oleh penggalian atau penimbunan lereng untuk jalan, perumahan maupun rel kereta. Akibat dari adanya gangguan pada lereng, maka massa tanah/batuan akan mencari keseimbangan baru akibat adanya faktor yang mempengaruhi dan menyebabkan berkurangnya kuat geser dan meningkatnya tegangan geser pada massa tanah/batuan tersebut.

Jadi, banyak faktor yang mempengaruhi stabilitas lereng yang mengakibatkan terjadi longsoran. Longsoran sangat jarang terjadi karena salah satu faktor penyebab. Adapun sebab-sebab longsoran lereng alam terjadi menurut Hardiyatmo [2] yaitu:

1. Penambahan beban pada lereng seperti beban bangunan yang baru, beban air yang masuk ke pori-pori tanah yang menggenang dipermukaan

2. Penggalian atau pemotongan tanah pada kaki lereng

3. Penggalian yang mempertajam kemiringan lereng

4. Kenaikan tekanan lateral oleh air (air yang mengisi retakan yang akan mendorong tanah ke arah lateral)

5. Penurunan tahanan geser tanah pembentuk lereng oleh akibat kenaikan kadar air, kenaikan tekanan air pori, tekanan rembesan oleh genakan air di dalam tanah.

6. Getaran atau gempa.

\section{Tegangan - regangan dalam tanah}

Tegangan yang terjadi dalam tanah diakibatkan oleh bermacam - macam pembebanan berdasarkan teori elastisitas, sekalipun tanah pada umumnya tidak elastis penuh, tidak isotropis dan tidak juga homogen, perhitungan untuk memperkirakan besarnya kenaikan tegangan akibat berat sendiri tanah.

1. Tegangan normal total

Merupakan perkalian dari berat volume tanah $(\Upsilon)$ dengan kedalaman titik yang ditinjau (z). Dengan tidak memperhitungkan pengaruh air, maka besarnya tegangan normal total adalah sebagai berikut:

$$
\sigma=\Upsilon . \mathrm{z}
$$

\section{Tegangan efektif}

Merupakan tegangan dalam tanah yang disebabkan oleh gaya-gaya air yang terdapat di dalam tanah. Pada kondisi tanah jenuh air, Terzaghi mengubah persamaan Mohr - Coulomb dalam bentuk tegangan efektif $\left(\sigma^{\prime}\right)$ yang dipengaruhi oleh tekanan air pori $(\mathrm{u})$ :

$$
\begin{aligned}
& \tau=c^{\prime}+\sigma^{\prime} \tan \varphi^{\prime} \\
& \tau=c^{\prime}+(\sigma-u) \tan \varphi^{\prime}
\end{aligned}
$$

\section{Analisis stabilitas lereng}

Analisis stabilitas lereng dilakukan untuk mengetahui kondisi suatu lereng baik lereng alami maupun lereng buatan. Tujuan analisis stabilitas lereng adalah memperkirakan bentuk keruntuhan dan tingkat kerawanan lereng terhadap longsoran serta merancang lereng timbunan supaya memenuhi kriteria keamanan.

Berdasarkan persamaan tegangan geser tanah Mohr-Coulomb (1776) dalam Craig [3], kekuatan geser tanah yang tersedia atau yang dikerahkan oleh tanah adalah:

$$
\tau=\mathrm{c}+\sigma \tan \varphi
$$

Metode analisis stabilitas lereng yang digunakan dalam penelitian ini adalah teknik reduksi kekuatan geser (strength reduction technique) metode elemen hingga. Dalam teknik reduksi (pengurangan) kekuatan geser tanah, parameter kuat geser tanah c' dan $\varphi^{\prime}$ yang tersedia berturut-turut direduksi secara otomatis sampai 
menyebabkan keruntuhan [4]. Nilai reduksi dari parameter kuat geser seperti persamaan:

$$
\begin{aligned}
c^{\prime} f & =\frac{c^{\prime}}{\operatorname{SRF}} \\
\varphi^{\prime} f & =\tan ^{-1}\left(\frac{c^{\prime}}{S R F}\right)
\end{aligned}
$$

dengan, SRF merupakan faktor pengurangan kekuatan (strength reduction factor) saat runtuh. Nilai SRF adalah sama dengan nilai faktor aman (SF) saat runtuh.

Sower (1979) dalam Liu [5] memberikan faktor aman untuk galian dan timbunan, yaitu $\mathrm{SF}<1$ (tidak aman), $1 \leq \mathrm{SF} \leq 1,2$ (lereng meragukan) dan $S F>1,2$ (aman).

\section{Analisis deformasi dengan plaxis}

Perilaku tanah dan bangunan struktur yang menerima beban dapat dianalisis dengan menggunakan konsep metode elemen hingga. Untuk memudahkan perhitungan dengan metode elemen hingga, yaitu dengan program Plaxis [6]. Simulasi numeris dengan Plaxis dapat menghitung besarnya deformasi timbunan dan tanah secara 2D serta dapat digunakan untuk menganalisis stabilitas dari tanggul. Metode simulasi numeris dapat di idealisasi dengan konsep plane strain 2D, dimana beban bekerja sepanjang struktur pada bidang $\mathrm{x}-\mathrm{y}$. Displacement dan regangan pada arah sumbu $\mathrm{z}$ sama dengan nol sedangkan komponen displacement arah $\mathrm{x}, \mathrm{y}$ yaitu $\mathrm{u}, \mathrm{v}$.

Model material yang sering digunakan dalam simulasi numeris adalah model MohrCoulomb yang merupakan model elasto plastis. Model elastis menggambarkan tegangan yang menyebabkan regangan hingga kondisi leleh dan plastis menggambarkan perilaku pasca leleh akibat meningkatnya regangan. Parameter MohrCoulomb, yaitu modulus elastisitas (E) dan Poisson ratio $(v)$ yang mewakili elastisitas tanah, kohesi (c) dan sudut gesek dalam $(\varphi)$ mewakili plastisitas tanah dan sudut dilatancy $(\psi)$.

\section{METODOLOGI PENELITIAN}

Lokasi penelitian adalah Ruas Jalan Ampenan - Pemenang KM. 12+800 (MTR) Desa Senggigi Kecamatan Batu Layar Kabupaten Lombok Barat Provinsi Nusa Tenggara Barat. Metode yang digunakan adalah survei lapangan dan pengumpulan data primer (topografi, data geologi, data penyelidikan geoteknik, data sifat fisik dan sifat mekanik tanah/batuan). Melakukan kajian dan analisis data yang dipakai sebagai parameter input dalam simulasi numeris dengan Plaxis. Simulasi dilakukan dengan idealisasi $2 D$ pada kondisi plane strain dengan model Mohr-Coulomb untuk tanah/batuan dasar, sedangkan dinding penahan berupa pasangan batu dan trotoar beton dengan materialnya didekati model linear elastic.

\section{HASIL DAN PEMBAHASAN}

\section{Hasil}

1. Geologi Daerah Penelitian

Geomorfologi lokasi penyelidikan merupakan morfologi perbukitan bergelombang dengan kemiringan lereng antara $70^{\circ}$ hingga $85^{\circ}$ (derajat). Kondisi geologi permukaan daerah penyelidikan berupa endapan aluvium hasil pelapukan batuan yang terdiri dari pasir lanauan berwarna coklat yang bersifat lepas dan belum terjadinya proses litifikasi. Singkapan batuan dasar berupa breksi andesit dengan pelapukan rendah hingga pelapukan sedang (grade III: kurang dari 35\% batuan telah lapuk jadi tanah). Struktur geologi berupa kekar-kekar minor pada lereng sedangkan bidang sesar tidak dijumpai.

2. Penyelidikan Geoteknik

Penyelidikan geoteknik dilakukan untuk mendapatkan data dan gambaran mengenai keadaan, jenis dan sifat-sifat tanah di lokasi penyelidikan yang meliputi pengambilan contoh tanah (core sampling), pengujian daya dukung standard (N-SPT) dan pengamatan muka air tanah. Hasil 
penyelidikan geoteknik berupa bore log seperti pada Tabel 1 [7]. Penyelidikan geoteknik dilakukan di bahu jalan sebelah kiri dengan kedalaman hingga 25.0 meter dari permukaan tanah.

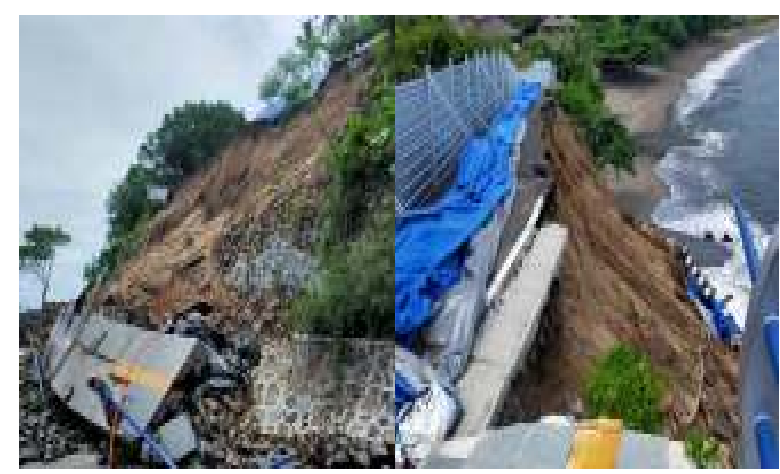

Gambar 1. Model Longsoran

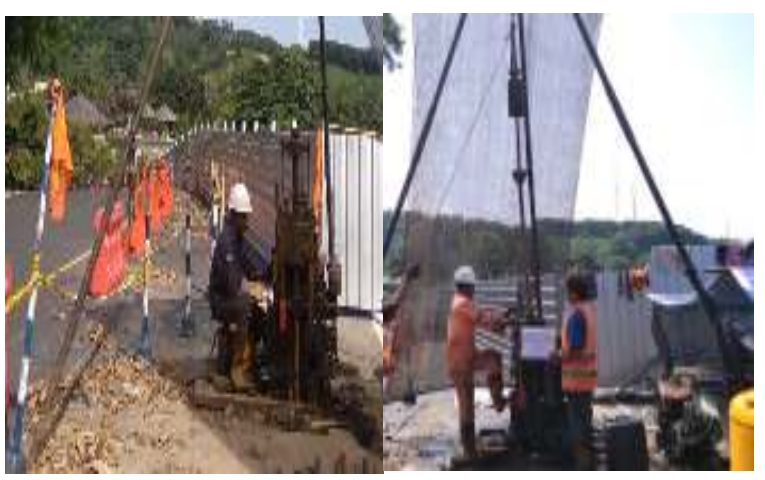

Gambar 2. Penyelidikan Geoteknik

Tabel 1. Hasil Penyelidikan Geoteknik

\begin{tabular}{clll}
\hline $\begin{array}{c}\text { Kedalaman } \\
(\boldsymbol{m})\end{array}$ & Litologi & $\begin{array}{c}\text { Nilai } \\
\boldsymbol{N} \text {-SPT }\end{array}$ & $\begin{array}{c}\text { Kategori } \\
\text { kepadatan }\end{array}$ \\
\hline $0.0-2.0$ & $\begin{array}{l}\text { Pasir } \\
\text { Lanauan }\end{array}$ & \\
\hline $2.0-4.0$ & $\begin{array}{l}\text { Pasir } \\
\text { Lanauan }\end{array}$ & 47 & Padat \\
\hline $4.0-6.0$ & $\begin{array}{l}\text { Pasir } \\
\text { Lanauan }\end{array}$ & 27 & Sedang \\
\hline $4.0-6.0$ & $\begin{array}{l}\text { Pasir } \\
\text { Lanauan }\end{array}$ & 23 & Sedang \\
\hline $6.00-8.00$ & Breksi & $>60$ & $\begin{array}{l}\text { Sangat } \\
\text { Padat }\end{array}$ \\
\hline $8.0-10.0$ & Breksi & $>60$ & $\begin{array}{l}\text { Sangat } \\
\text { Padat }\end{array}$ \\
\hline
\end{tabular}

\begin{tabular}{cccl}
\hline $\begin{array}{c}\text { Kedalaman } \\
(\boldsymbol{m})\end{array}$ & Litologi & $\begin{array}{c}\text { Nilai } \\
\boldsymbol{N} \text {-SPT }\end{array}$ & $\begin{array}{c}\text { Kategori } \\
\text { kepadatan }\end{array}$ \\
\hline $10.0-12.0$ & Breksi & $>60$ & $\begin{array}{l}\text { Sangat } \\
\text { Padat }\end{array}$ \\
\hline $12.0-14.0$ & Breksi & $>60$ & $\begin{array}{l}\text { Sangat } \\
\text { Padat }\end{array}$ \\
\hline $14.0-15.0$ & Breksi & $>60$ & $\begin{array}{l}\text { Sangat } \\
\text { Padat }\end{array}$ \\
\hline $15.0-16.0$ & Breksi & & $\begin{array}{l}\text { Sangat } \\
\text { Padat }\end{array}$ \\
\hline $16.0-18.0$ & Breksi & $>60$ & $\begin{array}{l}\text { Sangat } \\
\text { Padat }\end{array}$ \\
\hline $18.0-20.0$ & Breksi & $>60$ & $\begin{array}{l}\text { Sangat } \\
\text { Padat }\end{array}$ \\
\hline $20.0-22.0$ & Breksi & $>60$ & $\begin{array}{l}\text { Sangat } \\
\text { Padat }\end{array}$ \\
\hline $22.0-24.0$ & Breksi & $>60$ & $\begin{array}{l}\text { Sangat } \\
\text { Padat }\end{array}$ \\
\hline $24.0-25.0$ & Breksi & $>60$ & $\begin{array}{l}\text { Sangat } \\
\text { Padat }\end{array}$ \\
\hline$>25.0$ & Breksi & $>60$ & $\begin{array}{l}\text { Sangat } \\
\text { Padat }\end{array}$ \\
\hline
\end{tabular}

Setelah penyelidikan lapangan selesai dilakukan, maka selanjutnya dilakukan pengujian laboratorium terhadap core sample untuk mendapatkan sifat fisik dan sifat mekanik tanah sehingga dapat digunakan sebagai parameter input dalam simulasi numeris.

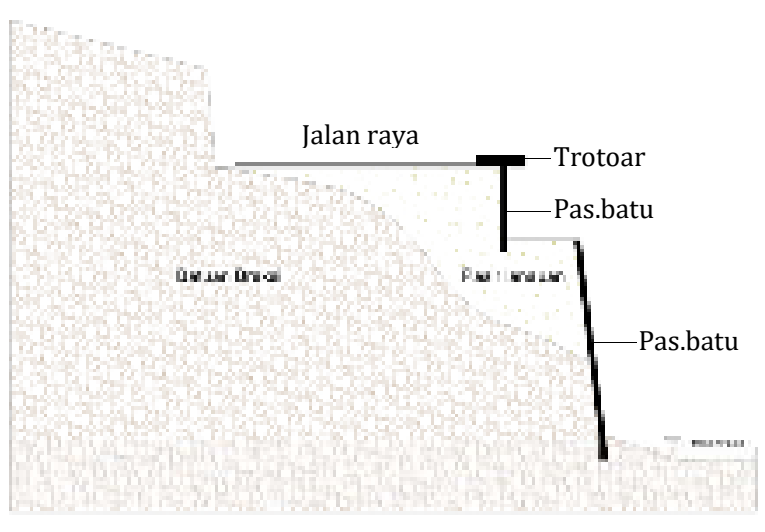

Gambar 3. Model Cross Section Lereng Jalan 


\section{Simulasi Numeris}

Pembuatan model numeris dengan software plaxis memerlukan adanya perlapisan tanah/batuan dasar, geometri lereng serta parameter input model. Geometri lereng dibuat berdasarkan cross section hasil pengukuran topografi, perlapisan tanah/batuan dari litologi core drilling, seperti pada Gambar 3. Sedangkan parameter input diperoleh dari hasil pengujian di laboratorium.

Untuk mengetahui perilaku tegangan dan regangan lereng jalan, maka dilakukan beberapa simulasi:

a. Simulasi kondisi sebelum terjadi kenaikan muka air tanah

b. Simulasi setelah kenaikan muka air tanah.

Tabel 2. Parameter Input Simulasi

\begin{tabular}{lllll}
\hline $\begin{array}{l}\boldsymbol{N} \\
\boldsymbol{o}\end{array}$ & $\begin{array}{l}\text { Jenis } \\
\text { material }\end{array}$ & $\begin{array}{c}\mathbf{Y}_{\mathbf{u n s a t}} \\
\mathbf{k N} / \mathbf{m}\end{array}$ & $\begin{array}{c}\mathbf{Y}_{\mathbf{u n s a t}} \\
\mathbf{k N} / \mathbf{m}\end{array}$ & $\begin{array}{c}\mathbf{K}_{\mathbf{x}}= \\
\mathbf{K}_{\mathbf{y}} \\
\mathbf{m} / \mathbf{d a} \\
\mathbf{y}\end{array}$ \\
\hline 1 & $\begin{array}{l}\text { Pasir } \\
\text { lanauan }\end{array}$ & 13.80 & 17.90 & 0.10 \\
\hline 2 & $\begin{array}{l}\text { Batuan } \\
\text { breksi }\end{array}$ & 13.20 & 17.40 & $\begin{array}{l}0.000 \\
1\end{array}$ \\
\hline 3 & $\begin{array}{l}\text { Pas.batu/t } \\
\text { rotoar }\end{array}$ & 24.00 & 24.00 & $\begin{array}{l}0.000 \\
1\end{array}$ \\
\hline
\end{tabular}

Tabel 3. Parameter Input Simulasi

\begin{tabular}{|c|c|c|c|c|c|}
\hline No & $\begin{array}{l}\text { Jenis } \\
\text { Mate } \\
\text { rial }\end{array}$ & $v$ & $\begin{array}{c}E \\
k N / \\
m^{3}\end{array}$ & $\begin{array}{c}c \\
k N / m^{3}\end{array}$ & $\emptyset_{0}^{\varnothing}$ \\
\hline 1 & $\begin{array}{l}\text { Pasir } \\
\text { lanau } \\
\text { an }\end{array}$ & $\begin{array}{l}0 . \\
30\end{array}$ & 5000 & 22.0 & 30.0 \\
\hline 2 & $\begin{array}{l}\text { Batu } \\
\text { an } \\
\text { breks } \\
\text { i }\end{array}$ & $\begin{array}{l}0 . \\
20\end{array}$ & $\begin{array}{l}50.00 \\
0\end{array}$ & 34.0 & 33.0 \\
\hline 3 & $\begin{array}{l}\text { Pas.b } \\
\text { atu/ }\end{array}$ & $\begin{array}{l}0 . \\
20\end{array}$ & $\begin{array}{l}100.0 \\
00\end{array}$ & & \\
\hline
\end{tabular}

\begin{tabular}{lllccc}
\hline & Jenis & & $\boldsymbol{E}$ & & \\
No & Mate & $\boldsymbol{v}$ & $\mathrm{kN} /$ & $\boldsymbol{c}$ & $\emptyset$ \\
& rial & & $\mathrm{m}^{3}$ & $\mathrm{kN} / \mathrm{m}^{3}$ & $\boldsymbol{0}$ \\
\hline & troto & & & \\
ar & & & & \\
\hline
\end{tabular}

a. Simulasi kondisi sebelum terjadi kenaikan muka air tanah

Perilaku lereng dan tanah/batuan dasar yang menerima beban dapat di analisis dan dievaluasi dengan menggunakan konsep dari metode elemen hingga. Salah satu alat untuk memudahkan perhitungan dengan metode elemen hingga, yaitu menggunakan program komputer Plaxis yang merupakan analisa secara numeris. Program Plaxis dapat menghitung besarnya perpindahan (displacement) dan distribusi tegangan-regangan pada lereng lapisan tanah/batuan. Pada penelitian ini, lereng dimodelkan secara dua dimensi (plane strain) dengan perilaku material tanah menggunakan model Mohr Coulomb (elastic-perfectly plastic). Model Mohr-Coulomb merupakan suatu constitutive model yang digunakan untuk menganalisa perilaku lereng dan tanah/batuan dasar akibat beban statis yang bekerja. Parameter input tanah/batuan dasar hasil pengujian laboratorium dan parameter lainnya, seperti Tabel 2. Kondisi tanah di lapangan pada umumnya sangat kompleks dengan tingkat heterogenitas, anisotropis maupun perilaku tanah dan kondisi lingkungan, seperti muka air tanah dan curah hujan. Sementara itu model numeris cukup sulit mengakomodasi berbagai hal tersebut secara detail sehingga perlu dilakukan penyederhanaan supaya mendekati kondisi kenyataan.

Beberapa asumsi yang digunakan dalam pemodelan adalah: 
1. Material tanah dasar untuk setiap lapisan adalah homogen dan isotropis.

2. Kedalaman muka air tanah sejajar dengan muka air laut.

3. Beban kendaraan diambil sebesar 20 ton dan kondisi trotoar serta dinding penahan tanah disesuaikan dengan model di lapangan.

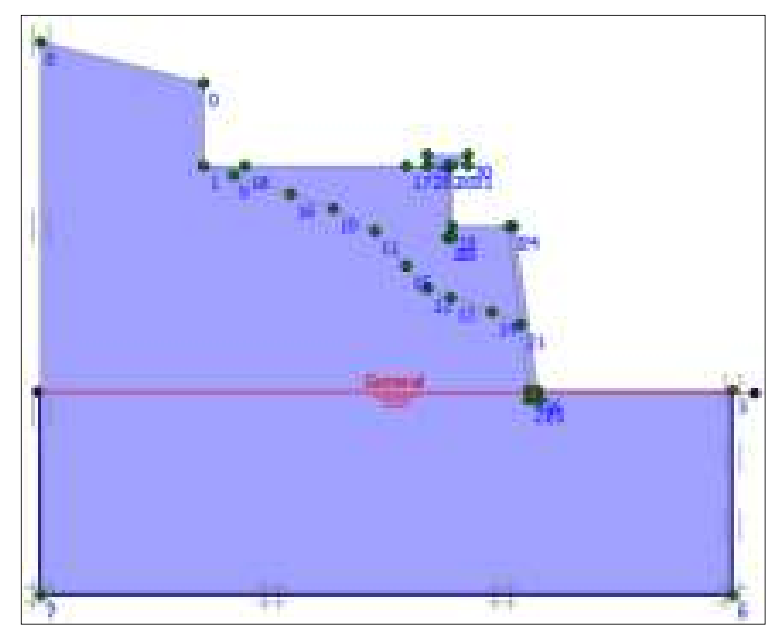

Gambar 4. Model Sebelum Terjadi Kenaikan Muka Air Tanah

b. Simulasi setelah kenaikan muka air tanah

Curah hujan tinggi yang terjadi sekitar bulan Januari - Februari menyebabkan muka air tanah naik. Kenaikan muka air tanah menyebabkan tanah menjadi jenuh sehingga rongga pori tanah akan terisi dengan air. Adanya air pori dalam tanah menyebabkan tekanan air meningkat sehingga terjadi penurunan tekanan efektif tanah. Untuk mengetahui apakah angka aman lereng meningkat atau menurun setelah naiknya muka air pori dapat dibuktikan pada saat simulasi dengan program Plaxis 2D.

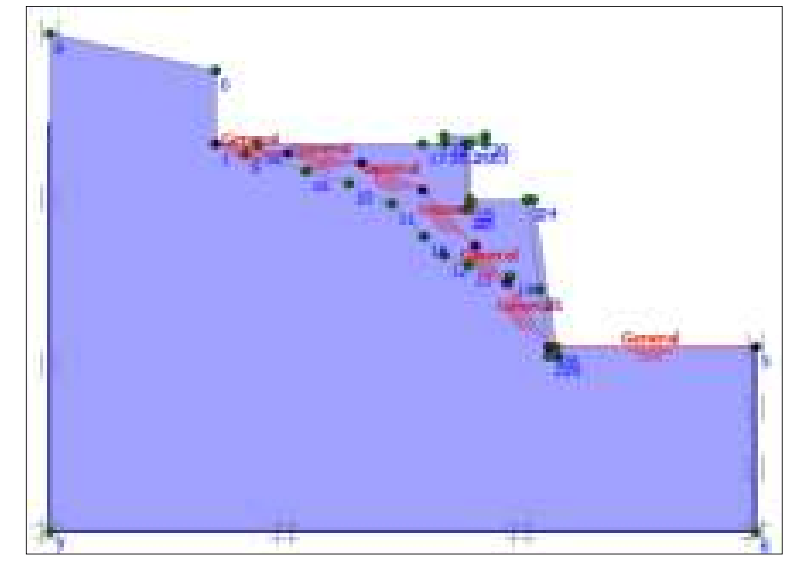

Gambar 5. Model Kenaikan Muka Air

\section{Pembahasan}

1. Perilaku Tegangan-Regangan

Secara garis besar, simulasi di bagi menjadi 2 (dua) tahap yaitu tahap pertama simulasi kondisi sebelum terjadi kenaikan muka air tanah, tahap kedua simulasi setelah kenaikan muka air tanah. Hasil simulasi numeris disajikan dalam bentuk displacement berupa total displacement, horizontal displacement dan vertical displacement. Berdasarkan nilai displacement dapat diketahui perilaku lereng dan tanah/batuan dasar, pengamatan di lapangan menunjukkan lereng telah mengalami gejala geologi sebelum terjadi longsoran, yaitu retakan memanjang sejajar jalan. Adanya retakan memanjang yang disertai curah hujan tinggi bisa menjadi pemicu terjadinya longsoran. Air yang masuk melalui retakan menyebabkan muka air tanah naik. Bertambah muka air menyebabkan tanah menjadi jenuh sehingga rongga pori terisi air dan bertambahnya tekanan air pori. Dengan bertambahnya tekanan air pori, maka tekanan efektif tanah menjadi berkurang sehingga berpotensi untuk terjadinya longsoran. Untuk membuktikan longsoran yang sudah terjadi akibat naiknya muka air tanah, maka dilakukan simulasi numeris dengan Plaxis 2D. Dari tampilan displacement yang merupakan bagian dari tegangan-regangan dapat 
diketahui arah total displacement pada lereng dan tanah dasar, baik displacement arah vertikal maupun horizontal.

a. Simulasi kondisi sebelum terjadi kenaikan muka air tanah

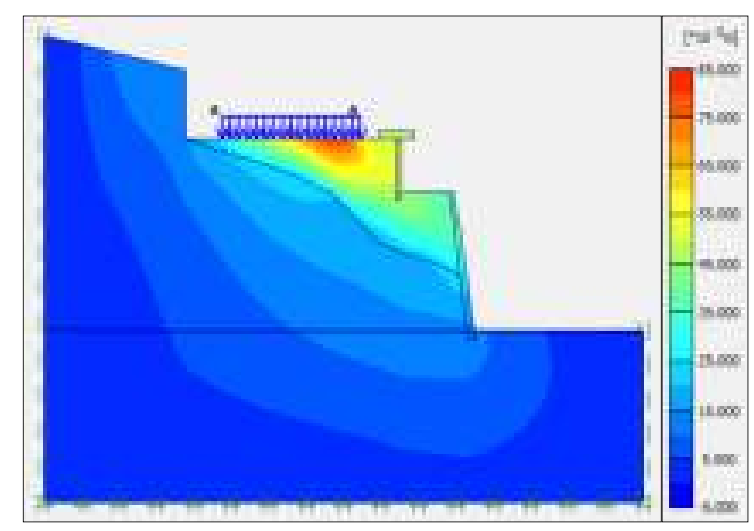

Gambar 6. Total Displacement (total disp.= $80.66 \times 10^{-3} \mathrm{~m}$ )

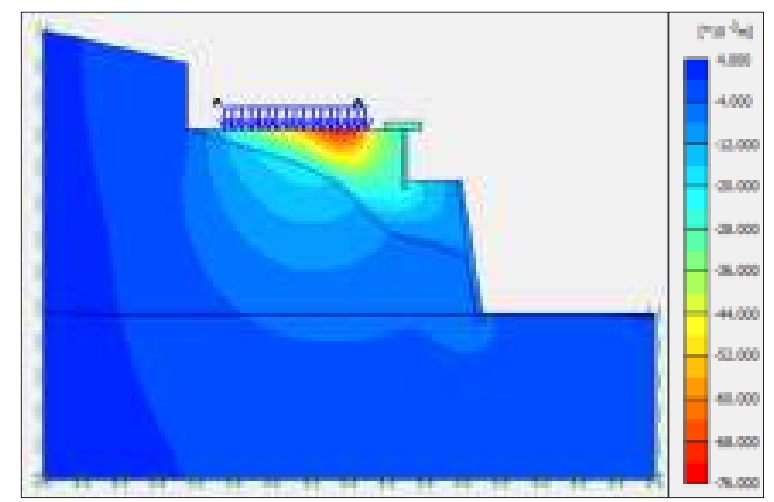

Gambar 7. Horizontal Displacement (Horizontal disp. $\left.=45.78 \times 10^{-3} \mathrm{~m}\right)$

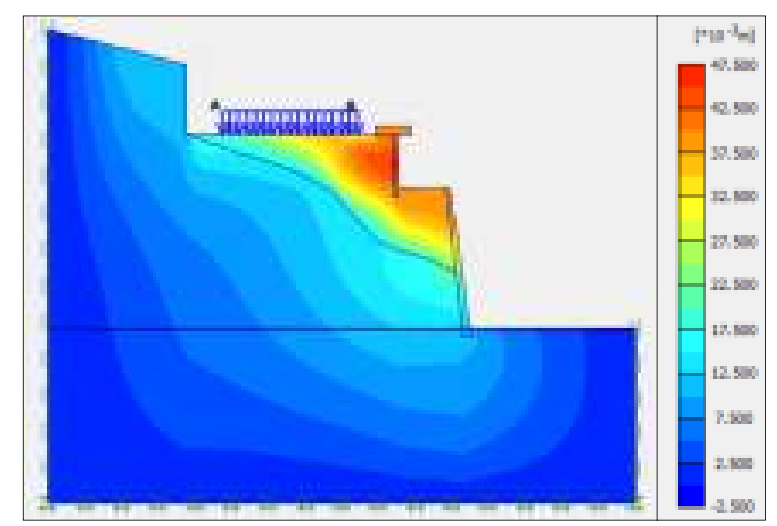

Gambar 8. Vertikal Displacement (Vertical disp. $=72.32 \times 10^{-3} \mathrm{~m}$ ) b. Simulasi akibat naiknya muka air tanah

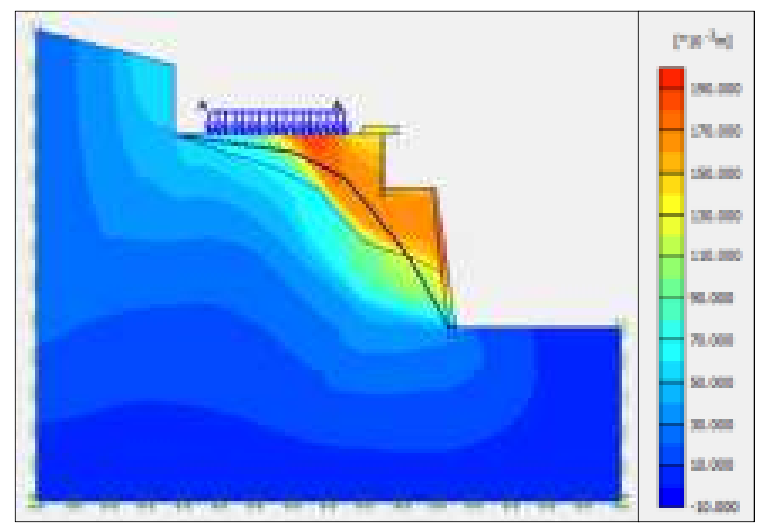

Gambar 9. Total Displacement (Total disp.= $189.95 \times 10^{-3} \mathrm{~m}$ )

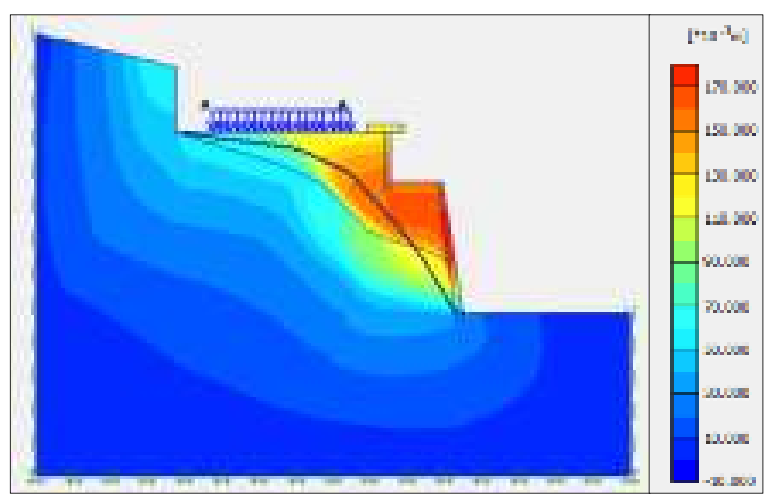

Gambar 10. Horizontal displacement (horizontal disp. $=179.23 \times 10^{-3} \mathrm{~m}$ )

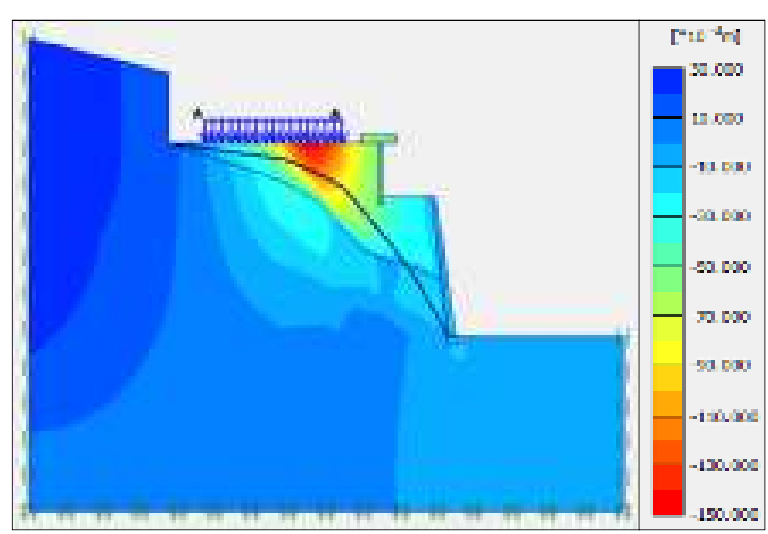

Gambar 11. Vertikal Displacement (Vertical disp $=146.04 \times 10^{-3} \mathrm{~m}$ ) 
Tabel 4. Nilai Displacement Masing-Masing Kondisi

\begin{tabular}{|c|c|c|c|c|}
\hline \multirow{2}{*}{ No } & \multirow{2}{*}{ Kondisi } & \multicolumn{3}{|c|}{ Displacement } \\
\hline & & Total & Horiz. & Verti. \\
\hline 1 & $\begin{array}{l}\text { kondisi } \\
\text { sebelum } \\
\text { kenaikan } \\
\text { muka air }\end{array}$ & $\begin{array}{l}80.66 \\
\times 10^{-3}\end{array}$ & $\begin{array}{l}45.78 \\
\times 10^{-3}\end{array}$ & $\begin{array}{l}72.32 \\
\times 10^{-3}\end{array}$ \\
\hline 2 & $\begin{array}{l}\text { kondisi } \\
\text { setelah } \\
\text { kenaikan } \\
\text { muka air }\end{array}$ & $\begin{array}{l}189.9 \\
5 \times 10^{-} \\
3\end{array}$ & $\begin{array}{l}179.2 \\
3 \times 10^{-} \\
3\end{array}$ & $\begin{array}{l}146.0 \\
4 \times 10 \\
3\end{array}$ \\
\hline
\end{tabular}

2. Stabilitas Lereng Jalan

Berdasarkan hasil simulasi numeris menunjukkan bahwa lereng sebelum terjadi kenaikan muka air tanah tergolong stabil (aman), hal ini ditandai dengan faktor angka aman yang cukup besar $(\mathrm{SF})=1.3379$.

Sebelum peristiwa longsoran terjadi, terlebih dahulu lereng jalan mengalami gejala geologi, yaitu adanya retakan memanjang sejajar jalan. Adanya retakan yang disertai curah hujan tinggi bisa menjadi pemicu terjadinya longsoran. Air yang masuk melalui retakan menyebabkan muka air tanah naik. Bertambah muka air menyebabkan tanah menjadi jenuh sehingga rongga pori terisi air dan bertambahnya tekanan air pori. Dengan bertambahnya tekanan air pori, maka tekanan efektif tanah menjadi berkurang sehingga berpotensi untuk terjadi longsor.

Simulasi numeris dengan Plaxis dilakukan untuk membuktikan kenaikan muka air tanah menjadi pemicu terjadinya longsor pada lereng. Dari hasil simulasi dengan adanya kenaikan muka air tanah menyebabkan lereng menjadi tidak stabil, hal ini dibuktikan dengan angka aman yang kecil yakni $\mathrm{SF}=1.1602$. Nilai angka aman tersebut kurang dari 1.2 sehingga lereng tersebut menjadi tidak stabil bahkan mengalami longsoran.
Tabel 5. Nilai Angka Aman Lereng

\begin{tabular}{llc}
\hline No & Kondisi & $\begin{array}{c}\text { Angka aman } \\
\text { (SF) }\end{array}$ \\
\hline \multirow{2}{*}{$\begin{array}{l}\text { kondisi sebelum } \\
\text { kenaikan muka } \\
\text { air }\end{array}$} & 1.3379 \\
\hline \multirow{2}{*}{$\begin{array}{l}\text { kondisi setelah } \\
\text { kenaikan muka } \\
\text { air }\end{array}$} & 1.1602 \\
\hline
\end{tabular}

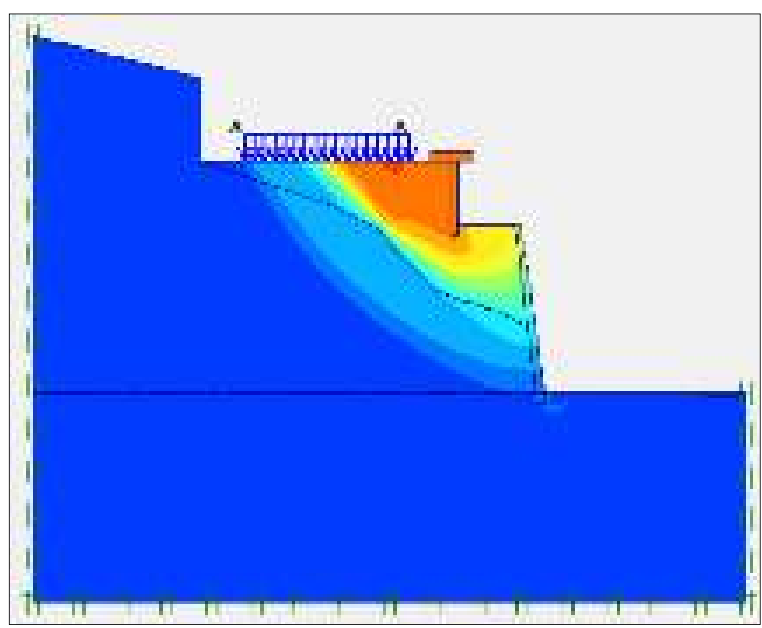

Gambar 12. Kondisi sebelum terjadi longsoran ( $\mathrm{SF}=1.3379$ )

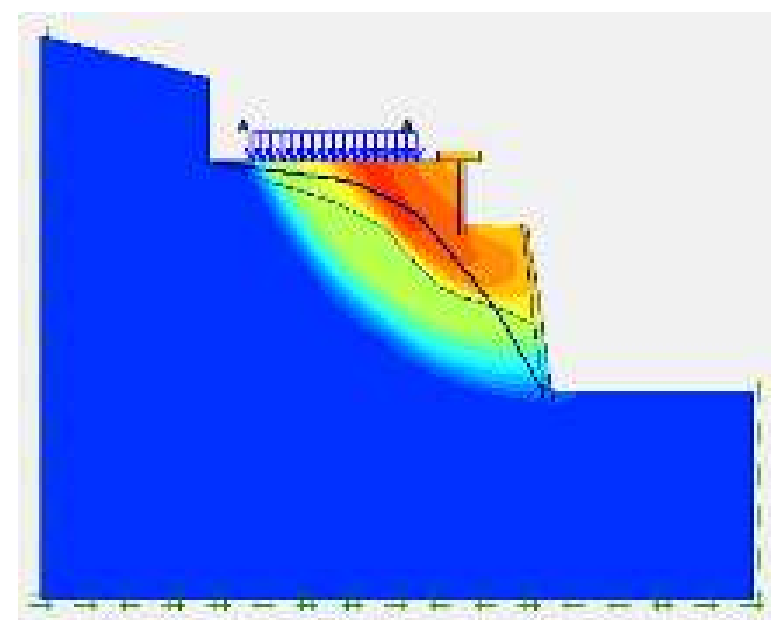

Gambar 13. Kondisi Setelah Terjadi Longsoran ( $\mathrm{SF}=1.1602)$

\section{KESIMPULAN}

Kesimpulan penelitian ini adalah sebagai berikut:

1. Tegangan - regangan yang terjadi pada lereng jalan mengalami 
peningkatan setelah muka air tanah mengalami kenaikan akibat curah hujan yang tinggi.

2. Curah hujan yang tinggi menyebabkan muka air tanah mengalami kenaikan sehingga lereng menjadi longsor hal ini ditandai dengan angka aman (SF) 1.1602 kurang dari syarat angka aman (SF) 1.20 .

\section{DAFTAR PUSTAKA}

[1] Anonim, "Laporan Penyelidikan Geoteknik Perencanaan Teknik Jalan dan Jembatan Provinsi Nusa Tenggara Barat TA. 2021 (DED)," CV. Rekayasa Bumi Karya, Nusa Tenggara Barat, 2021.

[2] Brinkgreve and Vermeer, Plaxis Version 7, A. A. Balkema. Netherland: Rotterdam, 2007.

[3] Craig. (1987). Mekanika Tanah. Erlangga, Jakarta.

[4] Farshidfar and Nayeri, "Slope stability analysis by Shear Strength Reduction Method," J. Civ. Eng. Urban., vol. 5, no. 1, pp. 35-37, 2015.

[5] Hardiyatmo, Mekanika Tanah II. Yogyakarta: Gajah Mada University Press, 2003.

[6] Karnawati, "Bencana Gerakan Massa Tanah/Batuan di Indonesia, Evaluasi dan Rekomendasi, Permasalahan, Kebijakan dan Penanggulangan Bencana Tanah Longsor di Indonesia, P3TPSLK-BPPT dan HSF," Jakarta, 2004.

[7] Liu and Evett, Soil and Foundations. New Jersey: Printice Hall, 1981. 
